\title{
PENGUJIAN EFISIENSI PASAR SETENGAH KUAT TERHADAP PENGUMUMAN PAKET KEBIJAKAN EKONOMI VII PADA SAHAM INDEKS LQ 45
}

\author{
Vivi Ariyani \\ Universitas Katolik Widya Mandala, Madiun \\ Email : viviariyaniuwm@yahoo.com
}

\begin{abstract}
Abstrak
Tujuan penelitian ini adalah menganalisis reaksi pasar pada pengumuman paket kebijakan ekonomi ketujuh pada saham Indeks LQ-45. kebijakan ekonomi tahap ketujuh fokus untuk memberikan kemudahan terhadap pelaku usaha padat karya, dan pedagang kaki lima. Sampel dalam penelitian ini sebanyak 42perusahaan tidak sedang melakukan corporate action, seperti merger dan akuisisi, stock split. Dari hasil menunjukkan bila abnormal return terjadi abnormal return positif dan negatif namun tidak signifikan, hanya pada hari ke-1 terjadi abnormal return dengan reaksi negatif sebelum pengumuman dan abnormal return dengan reaksi positif pada hari ke-9 setelah pengumuman. hal ini menjelaskan bahwa kebijakan VII pemerintah mendapatkan respon positif dari investor, karena pada kebijakan VII pemeritah memberikan perhatian tidak hanya pada perusahaan namun juga pada individu, seperti dalam paket ini terdapat kemudahan mendapatkan izin investasi, keringanan pajak untuk pegawai industri padat karya, dan kemudahan mendapatkan sertifikat tanah.
\end{abstract}

Kata Kunci: Paket Kebijakan VII, Abnormal Return

\begin{abstract}
The purpose of this study is to analyze the market reaction to the announcement of an economic policy package seventh the LQ-45 index stocks. The seventh stage of the economic policy focus to provide convenience to the labor-intensive businesses, and street vendors. The sample in this study as many as 42 companies are not doing corporate actions, such as mergers and acquisitions, stock splits, rights issue to issue a policy or bond issuance.From the results indicate abnormal return occurs when abnormal return of positive and negative but insignificant, only on days 1 occurs abnormal returns with negative reactions before the announcement and abnormal return with a positive reaction on the 9th day after the announcement. it is clear that the policy VII governments get a positive response from investors, due to the policy of VII Goverment give prhatian not only companies but also exploits also on the individual, as in this package are the ease of obtaining permits investment, tax relief for employees of labor-intensive industries, and the ease of getting land certificate.
\end{abstract}

Key Word:policy of VII Government, Abnormal Return 


\section{PENDAHULUAN}

\section{Latar Belakang}

Pasar modal merupakan tempat bertemunya perusahaan perusahaan emiten, yaitu perusahaan yang menerbitkan sekuritas dengan investor, yaitu pihak yang menyediakan dana. Ketika investor menanamkan dana yang dimilikinya ke dalam bentuk investasi surat berharga maka investor akan mengharapkan keuntungan optimal dengan tetap memperhatikan tingkat risiko. Hal yang dapat dilakukan oleh investor untuk mendapatkan keuntungan optimal adalah dengan tanggap menyerap informasi yang diumumkan. Informasi diperoleh melalui media atau pengumuman langsung dari Bursa Efek Indonesia. Tingkat kemampuan investor dalam menyerap dan menganalisis informasi yang diterima dapat memberikan keuntungan bagi investor untuk bijak dalam membuat keputusan investasi. Menurut Tandelilin (2010:339) pasar modal mencerminkan apa yang terjadi pada perekonomian makro karena nilai investasi ditentukan oleh aliran kas yang diharapkan serta tingkat return yang diisyarakatkan atas investasi tersebut dan kedua faktor tersebut dipengaruhi oleh perubahan lingkungan makro.

Saat ini pada pemerintahan yang dipimpin oleh Presiden Joko Widodo dan Jusuf Kalla, pemerintah mengeluarkan beberapa kebijakan ekonomi yang diharapkan dapat memperkuat perekonomian di Indonesia. Kebijakan pemerintah dimulai pada bulan September hingga November 2015 telah mengeluarkan tujuh kebijakan ekonomi. Hal ini dilakukan pemerintah karena kebijakan ekonomi merupakan salah satu peristiwa yang berdampak secara makro. Menurut Nashrilah (2015) kebijakan ekonomi tahap ketujuh fokus untuk memberikan kemudahan terhadap pelaku usaha padat karya, dan pedagang kaki lima. Pada paket kebijakan ekonomi tahap ketujuh mengenai keringanan pajak penghasilan pasal $21(\mathrm{PPh} 21)$ untuk perusahaan yang memiliki karyawan lebih dari 5.000 orang. Berikutnya mengenai revisi terhadap Peraturan Pemerintah No. 18/2015 tentang fasilitas pajak penghasilan untuk penanaman modal di bidang-bidang usaha tertentu dan/atau di daerah-daerah Tertentu. Menurut Hartono (2010:521) pengumuman yang berhubungan dengan pemerintah dapat mempengaruhi harga sekuritas. Selain itu kebijakan ekonomi ketujuh lebih spesifik tentang hubungan perusahaan dan tenaga kerja. Hal ini tentu saja akan berdampak pada perkembangan suatu perusahaan dalam jangka panjang, dan merupakan informasi bagi investor dalam melakukan strategi investasi. 
Hartono (2010:557) menjelaskan bahwa pasar dikatakan efisien bentuk setengah kuat jika investor bereaksi dengan cepat untuk menyerap abnormal return menuju ke harga keseimbangan yang baru. Apabila investor menyerap abnormal return dengan lambat, maka pasar dikatakan tidak efisien bentuk setengah kuat secara informasi. Reaksi pasar terhadap pengumuman publik tersebut ditunjukkan dengan perubahan harga saham yang diukur dengan menggunakan return sebagai nilai perubahan harga. Srianingsih dan Khoiruddin (2015) menjelaskan bahwa terdapat reaksi selama $t+2$ secara berturut-turut, hal ini menjelaskan bahwa terjadi efisensi pasar setengah kuat secara informasi.

Hasil penelitian lain yang bertentangan adalah Pamungkas, dkk (2015); menemukan bahwa investor di Indonesia tidak bereaksi terhadap pengumuman. Demikian juga Setiawan dan Hartono (2003); Marfuah(2006) menemukan bahwa investor di Indonesia tidak canggih dan masih native, sehingga tidak dapat bereaksi secara tepat.Pada penelitian ini penulis menggunakan objek penelitian pada Indeks LQ-45 karena perusahaan yang termasuk kedalam Indeks LQ-45 merupakan perusahaan yang memiliki kinerja keuangan yang baik dari seluruh sektor yang ada di Bursa Efek Indonesia. Berdasarkan latar belakang yang diuraikan, penulis tertarik untuk meneliti dengan judul Pengujian Efisiensi Pasar Setengah Kuat Terhadap Pengumuman Paket Kebijakan Ekonomi ketujuh Pada Saham Indeks LQ 45

\section{Rumusan Masalah}

Apakah terdapat reaksi pasar pada pengumuman paket kebijakan ekonomi ketujuh pada saham Indeks LQ-45 ?

\section{Tujuan Penelitian}

Menganalisis reaksi pasar pada pengumuman paket kebijakan ekonomi ketujuh pada saham Indeks LQ-45

\section{Manfaat Penelitian}

a. Manfaat Praktis

Memberikan bahan pertimbangan untuk membuat keputusan bagi investor yang akan berinvestasi di pasar modal berdasarkan informasi yang diumumkan oleh pemerintah 


\section{b. Manfaat Teoritis}

Menambah literatur mengenai efisiensi pasar bentuk setengah kuat, sebagai bahan referensi bagi penelitian selanjutnya.

\section{TINJAUAN PUSTAKA}

Efisiensi pasar bentuk setengah kuat, adalah salah satu bentuk pasar. Pasar dikatakan efisien bentuk setengah kuat jika harga-harga sekuritas secara penuh mencerminkan semua informasi yang dipublikasikan, termasuk informasi yang berada di laporan-laporan keuangan perusahaan emiten.Informasi yang dipublikasikan dapat berupa:

a. Informasi yang dipublikasikan yang hanya mempengaruhi harga sekuritas dari dari perusahaan yang mempublikasikan informasi tersebut.Informasi yang dipublikasikan merupakan informasi dalam bentuk pengumuman oleh perusahaan emiten, seperti pengumuman laba, pengumuman pembagian dividen, pengumuman merger dan akuisisi, pengumuman pergantian pemimpin perusahaan.

b. Informasi yang dipublikasikan mempengaruhi harga-harga sekuritas sejumlah perusahaan, seperti peraturan pemerintah yang hanya berdampak pada harga-harga sekuritas perusahaan yang terkena regulasi.

c. Informasi yang dipublikasikan yang mempengaruhi harga-harga sekuritas semua perusahaan yang terdaftar di pasar saham. Seperti peraturan pemeritah yang berdampak pada semua perusahaan emiten.

Paket kebijakan jilid VII merupakan bagian dari serangkaian kebijakan yang dikeluarkan pemerintah untuk merespon perlambatan ekonomi Indonesia dan dunia. Badan Koordinasi Penanaman Modal (BKPM) optimistis bahwa Paket Kebijakan Ekonomi Tahap VII yang diluncurkan oleh pemerintah akan berdampak positif pada peningkatan daya saing investasi sektor padat karya.Dalam paket kebijakan tersebut ada tiga poin utama yang berkaitan erat dengan peningkatan daya saing sektor padat karya.

Pertama, insentif tax allowance untuk industri garmen dan industri sepatu. Kedua, insentif keringanan pajak penghasilan $(\mathrm{PPh} 21)$ untuk kedua industri tersebut. dan ketiga, layanan izin investasi 3 jam yang menghasilkan 8 produk perizinan ditambah 1 surat booking tanah. 
Paket kebijakan yang diumumkan oleh Menteri Koordinator Bidang Perekonomian Darmin Nasution menunjukkan komitmen pemerintah terhadap sektor padat karya. Terlebih, dalam komunikasi dengan investor dikhawatirkan daya saing dibandingkan negara lain, terutama akibat cost of production yang lebih tinggi. "Paket kebijakan ini diharapkan berdampak positif tidak hanya bagi investor existing yang mengalami masalah, namun juga menarik minat investasi baru maupun perluasan di sektor padat karya tersebut".

Sesuai ketentuan pada kebijakan paket VII Perusahaan yang berhak mendapatkan fasilitas pengurangan $\mathrm{PPh} 21$ tersebut adalah perusahaan memperkerjakan minimal 5.000 orang, kemudian menyampaikan daftar pegawai perusahaan, serta hasil produksi yang diekspor minimal 50 persen dihitung dari hasil ekspor tahun sebelumnya. "Keringanan diberikan untuk laporan penghasilan kena pajak sampai Rp50 juta di bawah per tahun.

Pengujian kandungan informasi dan pengujian efisensi pasar bentuk setengah kuat merupakan dua pengujian yang berbeda. Menurut Hartono (2010) pasar dikatakan efisien bentuk setengah kuat bila investor bereaksi dengan cepat untuk menyerap abnormal return untuk menuju ke harga keseimbangan yang baru. Apabila investor menyerap abnormal return dengan lambat, maka pasar dikatakan tidak efisien bentuk setengah kuat secara informasi.Sedangkan apabila investor tidak bereaksi artinya informasi yang terjadi tidak menimbulkan abnormal return. Selain itu menurut Hanafi (2008) dalam pasar efisien bentuk setengah kuat ketika informasi dipublikasikan maka harga akan langsung berubah menyesuaikan informasi yang baru tersebut. Dapat terjadi dua kemungkinan reaksi dari pengumuman, yang pertama yaitu pasar bereaksi secara berlebihan (overreaction) dan kemungkinan kedua terjadi reaksi pasar terjadi secara lambat.

Informasi menjadi fokus penelitian adalah kebijakan ekonomi tahap ketujuh. Mulai bulan September hingga November2015 Pemerintahtelah mengeluarkan tujuh paket kebijakan ekonomi untuk memperbaiki memperkuat fondasi perekonomian di Indonesia. Nazhrillah (2015) menjelaskan bahwa Menteri Koordinator Bidang Perekonomian, Darmin Nasution memastikan penurunan tarif pajak penghasilan (PPh Pasal 21) untuk membantu ketahanan industri dalam negeri, masuk dalam paket kebijakan ekonomi jilid ketujuh. Pada kebijakan tahap ini perhatian pemerintah lebih fokus kepada pengusaha dan tenaga kerja di Indonesia. Hal ini dapat memberikan informasi kepada 
investor yang akhirnya akan berdampak pada terjadinya reaksi investor di sekitar tanggal pengumunan.

Pada penelitian terdahulu dari Srianingsih dan Khoiruddin (2015) menjelaskan bahwa terdapat reaksi selama $\mathrm{t}+2$ secara berturut-turut, hal ini menjelaskan bahwa terjadi efisensi pasar setengah kuat secara informasi. Sedangkan hasil penelitian dari Pamungkas, dkk (2015); Sitohang E dan Mekel P A (2015) menjelaskan bahwa investor di Indonesia tidak bereaksi terhadap pengumuman. Kemudian dari penelitian Setiawan dan Hartono (2003); Marfuah (2006) menemukan bahwa investor di Indonesia tidak dapat bereaksi secara tepat karena dalam kategori tidak canggih dan masih native. Dari hasil penelitian yang berbeda dan seriusnya pemerintahan saat ini pada pemulihan ekonomi di Indonesia dari beberapa kebijakan yang dikeluarkan terutama pada kebijkan ketujuh yang berdampak langsung bagi investor, maka hipotesis penelitian dirumuskan sebagai berikut.

\section{Hipotesis}

H1: Terdapat reaksi pasar pada pengumuman paket kebijakan ekonomi ketujuh pada saham Indeks LQ-45

\section{METODE PENELITIAN}

\section{Populasi dan Sampel}

Jenis penelitian yang digunakan dalam penelitian ini adalah studi peristiwa (event study). Menurut Hartono (2010) Penelitian ini adalah penelitian mengenai studi peristiwa (event study) merupakan studi yang mempelajari reaksi pasar terhadap suatu peristiwa yang informasinya dipublikasikan sebagai suatu pengumuman, dan event study digunakan untuk menguji kandungan informasi dari suatu pengumuman.

Jenis data yang digunakan adalah data sekunder, yaitu harga saham perusahaan yang termasuk ke dalam 1Q-45 periode Agustus-Januari 2015. Sedangkan periode jendela digunakan sepuluh hari sebelum (h-10) dan sepuluh hari sesudah $(\mathrm{h}+10)$ dari tanggal pengumuman paket kebijakan ekonomi jilid ketujuh. Alasan penentuan periode jendela sepuluh hari sebelum dan sesudah tanggal pengumuman adalah untuk menghindari faktor-faktor yang mempengaruhi harga saham dan volume perdagangan, seperti pengumuman bonus saham ataupun stock split. 
Reaksi pasar di ukur dengan melihat perbedaan abnormal return dan aktivitas volume perdagangan saham sebelum dan setelah pengumuman paket kebijakan ekonomi jilid ketujuh. Harga saham yang dimaksudkan dalam penelitian ini adalah harga saham harian perusahaan pada saat penutupan (Closing price).

\section{HASIL DAN PEMBAHASAN}

\section{Desain Penelitian}

Jenis penelitian pada penelitian ini adalah penelitian event studyatau lebih dikenal dengan studi peristiwa, yaitu penelitian yang menganalisis reaksi pasar atas informasi yang diumumkan, dalam hal ini inveistor dapat memberikan reaksi atau tidak bereaksi atas informasi yang diumumkan. Peristiwa yang diteliti adalah pengumuman paket kebijakan VII yang dikeluarkan pada Desember 2015 sebagai bagian dari paket kebijakan pemerintah tahun 2015 .

\section{Populasi dan Sampel}

Tabel 1. Proses Pengambilan Sampel

\begin{tabular}{|c|l|c|}
\hline No & \multicolumn{1}{|c|}{ Kriteria Sampel Penelitian } & Jumlah \\
\hline 1. & $\begin{array}{l}\text { Perusahaan yang terdaftar di Indeks LQ-45 } \\
\text { selama periode jendela }\end{array}$ & 45 \\
\hline 2. & $\begin{array}{l}\text { Perusahaan yang tidak menggunakan harga } \\
\text { penutupan setiap hari }\end{array}$ & 0 \\
\hline 3 & $\begin{array}{l}\text { Perusahaan yang melakukan corporate action } \\
\text { seperti merger dan akuisisi, pembagian dividen, } \\
\text { stock split, kebijakan right issue, IPO dan } \\
\text { warrant atau penerbitan obligasi }\end{array}$ & 3 \\
\hline \multicolumn{2}{|l}{ Jumlah perusahaan yang memenuhi kriteria sampel } & 42 \\
\hline
\end{tabular}

Hipotesis penelitian ini menguji reaksi pasar pada pengumuman paket kebijakan VII pada saham Indeks LQ-45. Berdasarkan hasil pengolahan data maka hasilnya adalah sebagai berikut : 
Tabel 2. One Sample Statistic

One-Sample Statistics

\begin{tabular}{|l|r|c|r|c|}
\hline & $\mathrm{N}$ & Mean & Std. Deviation & $\begin{array}{c}\text { Std. Error } \\
\text { Mean }\end{array}$ \\
\hline stlh_10 & 42 & -.0004496 & .02019215 & .00311572 \\
stlh_9 & 42 & .0094584 & .02688931 & .00414911 \\
stlh_8 & 42 & -.0018299 & .01910036 & .00294725 \\
stlh_7 & 42 & -.0044138 & .02059610 & .00317805 \\
stlh_6 & 42 & .0037683 & .03266344 & .00504008 \\
stlh_5 & 42 & -.0055609 & .02522790 & .00389275 \\
stlh_4 & 42 & .0041618 & .02400714 & .00370438 \\
stlh_3 & 42 & -.0136174 & .02596066 & .00400582 \\
stlh_2 & 42 & .0017697 & .03102689 & .00478755 \\
stlh_1 & 42 & .0031616 & .02663653 & .00411011 \\
t_0 & 42 & -.0006797 & .01924710 & .00296989 \\
sblm_1 & 42 & -.0074943 & .01599165 & .00246757 \\
sblm_2 & 42 & .0027164 & .02015091 & .00310935 \\
sblm_3 & 42 & -.0073716 & .03019485 & .00465917 \\
sblm_4 & 42 & .0083798 & .03125423 & .00482263 \\
sblm_5 & 42 & -.0039117 & .01514984 & .00233767 \\
sblm_6 & 42 & -.0011349 & .01761772 & .00271847 \\
sblm_7 & 42 & -.0020592 & .01474662 & .00227545 \\
sblm_8 & 42 & -.0040802 & .01929030 & .00297656 \\
sblm_9 & 42 & -.0004080 & .02152226 & .00332096 \\
sblm_10 & 42 & .0016065 & .02556977 & .00394550 \\
\hline & & & &
\end{tabular}

Tabel 3. One Sample Test

One-Sample Test

\begin{tabular}{|c|c|c|c|c|c|c|}
\hline & \multicolumn{6}{|c|}{ Test Value $=0$} \\
\hline & \multirow[b]{2}{*}{$\mathrm{t}$} & \multirow[b]{2}{*}{ df } & \multirow[b]{2}{*}{ Sig. (2-tailed) } & \multirow{2}{*}{$\begin{array}{c}\text { Mean } \\
\text { Difference }\end{array}$} & \multicolumn{2}{|c|}{$\begin{array}{l}95 \% \text { Confidence } \\
\text { Interval of the } \\
\text { Difference }\end{array}$} \\
\hline & & & & & Lower & Upper \\
\hline sth_10 & -.144 & 41 & .886 & -.00044964 & -.0067420 & .0058427 \\
\hline stlh_9 & 2.280 & 41 & .028 & .00945839 & - 0010791 & 0178377 \\
\hline sth_8 & -.621 & 41 & .538 & -.00182989 & -.0077820 & . 0041222 \\
\hline stlh_7 & -1.389 & 41 & .172 & -.00441383 & -.0108320 & .0020044 \\
\hline stlh_6 & .748 & 41 & .459 & .00376834 & -.0064103 & 0139470 \\
\hline stlh_5 & -1.429 & 41 & 161 & -.00556089 & -.0134225 & .0023007 \\
\hline stlh_4 & 1.123 & 41 & 268 & .00416178 & -.0033194 & .0116429 \\
\hline sth_3 & -3.399 & 41 & .002 & -.01361739 & -.0217073 & -.0055275 \\
\hline sth_2 & 370 & 41 & .714 & .00176972 & -.0078989 & .0114384 \\
\hline stlh_1 & .769 & 41 & 446 & .00316162 & -.0051389 & 0114621 \\
\hline t_0 & -.229 & 41 & .820 & -.00067973 & -.0066775 & 0053181 \\
\hline sblm_1 & -3.037 & 41 & .004 & -.00749434 & -.0124777 & -.0025110 \\
\hline sblm_2 & .874 & 41 & .387 & .00271636 & -.0035631 & .0089958 \\
\hline sblm_3 & -1.582 & 41 & .121 & -.00737160 & -.0167810 & .0020378 \\
\hline sblm_4 & 1.738 & 41 & .090 & .00837983 & -.0013597 & 0181193 \\
\hline sblm_5 & -1.673 & 41 & .102 & -.00391174 & -.0086328 & .0008093 \\
\hline sblm_6 & -.417 & 41 & .678 & -.00113493 & -.0066250 & .0043551 \\
\hline sblm_7 & -.905 & 41 & .371 & -.00205925 & -.0066546 & .0025361 \\
\hline sblm_8 & -1.371 & 41 & 178 & -.00408021 & -.0100915 & - 0019311 \\
\hline sblm_9 & -.123 & 41 & .903 & -.00040804 & -.0071149 & .0062988 \\
\hline sblm_10 & .407 & 41 & .686 & .00160649 & -.0063616 & . 0095746 \\
\hline
\end{tabular}


Pengujian one sample test untuk semua sampel pada saat sebelum dan sesudah pengumuman paket kebijakan VII. Hasil pengujian reaksi pasar menunjukkan terjadi abnormal return signifikan bila $(<0,05)$.Hasil pengujian menunjukkan terjadi abnormal return pada hari ke-1 sebelum pengumuman dan hari ke-9 sesudah pengumuman, sedangkan pada saat periode jendela yaitu hari ke-0 tidak terjadi abnormal return yang signifikan. Dari hasil menunjukkan bila abnormal return terjadi abnormal return positif dan negatif namun tidak signifikan, hanya pada hari ke-1 terjadi abnormal return dengan reaksi negatif sebelum pengumuman dan abnormal return dengan reaksi positif pada hari ke-9 setelah pengumuman. Hal ini diduga terjadi karena pemerintah pernah membatalkan pengumuman kebijakan VII pada saat bulan November, kemudian diundur diumumkan menjadi tanggal 5 Desember 2015. Namun setelah pengumuman investor mulai merasakan dampak dari kebijakan VII, hal ini dapat terlihat dari hasil reaksi investor yang positif pada hari ke-9 setelah pengumuman. Sehingga hal ini menjelaskan bahwa kebijakan VII pemerintah mendapatkan respon positif dari investor, karena pada kebijakan VII pemeritah memberikan prhatian tidak hanya pada perusahaan namu juga pada individu, seperti dalam paket ini terdapat kemudahan mendapatkan izin investasi, keringanan pajak untuk pegawai industri padat karya, dan kemudahan mendapatkan sertifikat tanah.

Pada saat pengumuman paket VII, Menteri Koordinator Perekonomian Darmin Nasution (http://www.kompasiana.com) mengungkapkan, substansi pertama dalam paket kebijakan VII adalah penambahan kemudahan pada izin investasi. Jika sebelumnya 
diperlukan waktu tiga jam untuk mendapatkan empat izin, maka kemampuannya kali ini ditingkatkan oleh Badan Koordinasi Penanaman Modal menjadi sembilan izin dalam waktu tiga jam. Kedua, keringanan pajak penghasilan $(\mathrm{PPh})$ bagi industri padat karya selama 2 tahun.

Keringanan PPh ini akan dievaluasi, dan bisa diperpanjang melalui penerbitan peraturan pemerintah. Wajib pajak yang memenuhi persyaratan industri padat karya dapat mengajukan permohonan untuk memperoleh fasilitas ini. Guna mendapatkan fasilitas itu, perusahaan harus memiliki tenaga kerja minimal 5.000 orang. Setelah itu, perusahaan tersebut harus menyampaikan daftar pegawai yang akan diberikan keringanan.

Selanjutnya, hasil produksi yang diekspor oleh perusahaan padat karya minimal 50 persen berdasarkan hasil produksi tahun sebelumnya. Keringanan diberikan untuk lapisan kena pajak sampai dengan Rp 50 juta. Fasilitas keringanan berupa pengurangan $\mathrm{PPh}$ sebesar 50 persen dari angka yang ditetapkan tahun ini. Aturan ini berlaku mulai 1 Desember 2016. Substansi kedua masih menyangkut perusahaan padat karya. Selain itu terdapat perubahan Peraturan Pemerintah Nomor 18 Tahun 2015 mengenai fasillitas pajak penghasilan untuk penanaman modal di wilayah tertentu.

Ilustrasinya bila investasi 100 persen, perusahaan hanya akan diperhitungkan dalam perhitungan pajak 95 persen, sehingga diberikan fasilitas 5 persen selama 6 tahun. Keringanan yang akan dirasakan oleh perusahaan selanjutnya adalah, diberikan pengurangan dividen yang dibayarkan subyek pajak luar negeri dari 20 persen menjadi 10 persen. Blla perusahaan menderitakerugian, ruginya dapat diperhitungkan pada tahun setelahnya untuk mengurangi pembayaran pajaknya. Fasilitas keringanan pajak ini juga diperpanjang dari 5 tahun menjadi 10 tahun. Jenis industri yang mendapat fasilitas ini juga meliputi industri alas kaki, industri sepatu olahraga, industri sepatu teknik lapangan, industri pakaian jadi, serta pakaian berbahan kulit. Sedangkan aturannya akan dimasukkan oleh pemerintah didalam lampiran PP 18 Tahun 2015.

Dengan penambahan ini, industri tersebut dapat memperoleh fasilitas pajak di semua provinsi tanpa terkecuali. Selanjutnya substansi ketiga mengenai percepatan kemudahan sertifikasi tanah rakyat dalam rangka kepastian hak atas tanah dan mendorong pembangunan ekonomi masyarakat.Kebijakan ini akan dimulai dari pemberian sertifikat tanah untuk pedagang kaki lima, petani. 


\section{SIMPULAN DAN SARAN}

\section{Simpulan}

Berdasarkan hasil pengujian dan analisis terhadap abnormal return dari kebijakan VII yang dikeluarkan oleh pemerintah, maka hasil penelitian ini dapat disimpulkan sebagai berikut :

a. Terjadi abnormal return dari kebijakan VII, hal ini menjelaskan bahwa terjadi efisiensi pasar secara informasi bentuk setengah kuat pada perusahaan yang termasuk LQ-45.

b. Terjadi abnormal return pada hari ke-1 sebelum pengumuman kebijkan VII dengan reaksi secara negatif. Reaksi negatif ini diduga karena investor belum yakin akan terealisasinya paket kebijakan VII, karena kebijkan VII yang pada awalnya akan diumumkan pada masyarakat pada bulan November 2015 pemerintah menunda, yang pada akhirnya terealisasi diumumkan pada tanggal 5 November 2015.

c. Terjadi abnormal return pada hari ke-9 setelah pengumuman kebijakan VII. Pada hari ke-9 ini investor bereaksi positif. Hal ini diduga karena investor telah merasakan manfaat dari kebijakan VII bagi perusahaan. Seperti pengurangan pajak bagi perusahaan dengan karyawan minimal 5000 orang dan kemudahan mengurus ijin operasi perusahaan.

\section{Saran}

Berdasarkan hasil penelitian mengenai efisiensi pasar bentuk setengah kuat secara informasi terhadap kebijakan VII yang dikeluarkan oleh pemerintah, maka saran dari penulis adalah sebagai berikut :

a. Bagi investor sebaiknya mengikuti terus perkembangan informasi, baik dari pemerintah maupun informasi lainnya, agar dapat berinvestasi secara meguntungkan dan memperkecil risiko.

b. Penelitian ini adalah menguji efisiensi pasar bentuk setengah kuat secara informasi. Penelitian selanjutnya diharapkan melakukan penelitian dengan pengujian efisiensi pasar bentuk setengah kuat secara keputusan, dengan demikian dapat membedakan apakah investor di Indonesia telah canggih atau belum dalam membedakan pengumuman yang bernilai ekonomi dan yang tidak bernilai ekonomis. 
c. Pemerintah diharapkan dapat membuat kebijakan yang akan dapat selalu mendukung perkembangan usaha di Indonesia ke arah yang lebih baik lagi.

\section{DAFTAR PUSTAKA}

Hanafi, Mamduh. 2008. Manajemen Keuangan. Yogyakarta. BPFE

Hartono. 2010. Teori Portofolio dan Analisis Investasi. Edisi ketujuh. Yogyakarta.BPFE.

http://www.kompasiana.com/arfinsiemykompas/paket-kebijakan-ekonomi-bagaikanbom_55f3044b7eafbd340cfe8be2

Marfuah. 2006. Pengaruh Kecanggihan Investor Terhadap Ketepatan Reaksi Pasar Dalam Merespon Pengumunan Dividen Meningkat.JAAI Vol.10 No 2. Desember . Hal 137-154.

Tandelilin, Eduardus. 2010. Portofolio dan Investasi: Teori dan Aplikasi. Yogyakarta. Kanisius.

Pamungkas, dkk. 2015. Pengaruh Pemilu Presiden Indonesia Tahun 2014 terhadap Abnormal Return dan Trading Volume Activity (studi kasus perusahaan pada perusahaan yang tercatat sebagai anggota indeks kompas 100). Jurnal Administrasi Bisnis (JAB) Vol 20 No 1 Maret.

Sartono, Agus. 1996. Manajemen Keuangan. Edisi Ketiga. BPFE. Yogyakarta.

Sitohang E dan Mekel P A. 2015. Reaksi Pasar Modal terhadap Pemilihan Umum Presiden Tanggal 9 Juli 2014 di Indonesia.Jurnal EMBA. Vol.3 No.1 Maret. Pp.951-960.

Srianingsih dan Moh.Khoiruddin. 2015. Pengaruh Pengumuman Peringkat Sukuk Terhadap Reaksi Pasar. Management Analysis Journal. Unes. ISSN 22526552.

Sugiyono. 2008. Metode penelitian Bisnis. Bandung. Alfabeta. 